\title{
Money Laundering in Albania for the Years 2008-2015
}

\author{
Bajram Ibraj
}

$\mathrm{PhD}$ Cand.

\begin{abstract}
Study on Money laundering in Albania for the years 2008-2015, present typologies, the most prevalent forms through the banking system, the real estate sector, transfer companies and foreign exchange bureaus, and the most common forms of money laundering by free non-financial professions and other forms in Albania, with specific data. Present on the work of statistical data through tables and graphs, made possible through the development of concrete analysis of their comparisons on their own, thus reflecting typologies, forms and methods of money laundering in Albania for the years 2008-2015. In the context the detection and investigation of money laundering remains informal economy problem and transportation of cash at the entrance/exit of the border crossing points, which have been identified that are identified as the main risk of criminal product. Meanwhile, law enforcement to prevent and fight organized crime and trafficking through preventive measures against property and corruption remains far from the expectations and opportunities that this law grants within the confiscation of criminal products. Conclusions to improve work in terms of legislation, relevant structures, cooperation, and the implementation in practice and recommendations for further improvements to the security of citizens in general looked at closely by the services of the State Police, investigations and proceedings, in terms of criminal offense in the fight against organized crime, terrorism and corruption, significantly influences in the field of money laundering. At the origin of money laundering is any criminal activity, also held out, which generates money, often called "dirty", and/or other goods.
\end{abstract}

Keywords: Money laundering, typologies, prevention, banking system, suspicious activities

\section{Introduction}

"Money laundering is the circulation and recycling of money derived from criminal activity, hereinafter referred to as" dirty ". The purpose of money laundering is the concealing or covering their illicit origin. The importance lies in the fact that the aim, objective and scope of transnational organized crime is the profit. And benefits can not be achieved otherwise except money laundering, so the money crime, criminal groups to return them to "clean" money. PhD Naim Mëçalla researcher says: "The phenomenon and the concept of money laundering begins with the story of the father of the Mafia, Al Capone, who opened washers to gain the legitimacy of money he laid down on the street illegally. Through this method, he aimed to prove that the money earned he had them legitimate ...Al Capone was indicted for the first time in 1931 only to federal tax evasion during the years 1925 to 1929 and was sentenced to 11 years in prison.... ${ }^{2}$ While Prof. Dr. Luan Gjonça said: "The term Money Laundering, in the sense that it has today,for the first time it was used in the US in the 70-80 years of last century. The emergence of this phenomenon was due to revenue growth of criminal groups from the illegal trade of narcotics and their reinvestment in legitimate US economy. This phenomenon was named as the transformation of dirty money, obtained in non legitimate, the first "clean" backgrounds who were "legitimate"and that could enter freely in monetary circulation. ${ }^{3}$ Prof.Dr.Luan Gjonça says:"In the legislation this work was compensated with wording" Alienation and concealment of assets "that was provided for in section 287 of the "Criminal Code of the Republic of Albania" ... .This statement follows Prof.Dr.Gjonça did not meet the requirements of the offense of "Laundering proceeds of crime". ${ }^{4}$ While in our country the term Money Laundering was used for the first time in 2000 with the Law No.8610, dated 17.05.2000,

\footnotetext{
1Prof. Dr. Luan Gjonça Corruption, an integral offenses, organized crime, ILAR, Tirana, 2005

2Dr.Naim Mëçalla "Money laundering-Elements of criminal justice and crimonology",Tirana, 2013 page 19-20

3Prof.Dr.Luan Gjonça "Cleaning the proceeds of crime and organized crime ", 2000, page 2

http://juridiksi.e-monsite.com/faqe/e-drejta-penale/pastrimi-i-parava-te-pista.html

${ }^{4}$ lbid
} 
which in its Article 2 underlined:"... Money laundering is the circulation and recycling of money derived from criminal activity, hereinafter referred to as" dirty "...1

For the first time in the criminal legislation of the Republic of Albania the problem of dirty money laundering was arranged in satisfactory form in 2000 with the issuance of Law No. 8610, dated 17.05.2000, which in its Article 2 underlined: "...Money laundering is the circulation and recirculation of the derived money from the criminal activity, hereinafter referred to as" dirty $" . . .{ }^{2}$

Money laundering is an illegal act and punishable criminally sanctioned by the Law "On Prevention of Money Laundering"3 "the Criminal Procedure Code of the Republic of Albania 4"and" Penal Code of the Republic of Albania". ${ }^{5}$ Therefore, money laundering legislation in Albania is intended to harmonize the fight against money laundering and terrorist financing at global level.

Albania's national legislation complies with international standards outlined by the Financial Action Task Force (FATF) Financial Action Group against Money Laundering.FATF 6 issued 40 recommendations regarding the prevention of money laundering and 9 Special Recommendations on combating hte financing of terrorism, and was adopted after the September 11 attacks in 2001.Albania under the Convention of the Organization of the United Nations Convention against Transnational Organized Crime, Palermo, 2000, the Law No.8920, dated 11.7.20027 ratified the Convention and determined measures to combat money laundering (Article 7 of the law). ${ }^{8}$ During the 2002-2004 there have been taken important steps to improve the legislation in the fight against organized crime and to unify its alignment with international legislation. ${ }^{9}$

1 Law No.8610, dated 17.05.2000 "On Prevention of Money Laundering", page 1,Tirana, Official Gazette, July 2000;amended by Law Nr.9084, dated 19.06.2003 "On some amendments to Law No. 8610, dated 17.05.2000" On Prevention of Money Laundering "and the Law No. 9917, dated 19.15.2008," On prevention money laundering and terrorist financing" ${ }^{2}$ lbid

${ }^{3}$ Law No. 8610, dated 17.05.2000 "On the prevention of money laundering" law No.9084, dated 19.06.2003 "On some amendments to Law No. 8610, dated 17.05.2000 "On Prevention of Money Laundering "Law No. 9917, dated 19.15.2008," On the prevention of money laundering and terrorist financing"

4Law No. 9917, dated 19.15.2008, "On the prevention of money laundering and terrorist financing"

5Law No. 9085, dated 19.06.2003 "On some additions and amendments to Law No. 7905, dated 21.03.1995 "The Code of Criminal Procedure of the Republic of Albania"

${ }^{6}$ FATF was established by the G7 Summit held in Paris in July 1989 in response to the growing concerns of the international community about the dangers of money laundering

7The Convention of the United Nations against Transnational Organized Crime, Palermo, 2000, approved by Law No.8920, dated 11.7.2002 On the ratification of the "United Nations Convention Against Transnational Organized Crime" and its two Additional Protocols, promulgated by Decree No.3411, dated 22.07.2002, President of the Republic of Albania, Rexhep Meidani. Official Journal. 41, July 2002

${ }^{8}$ Law No.8920, dated 11.7.2002 On the ratification of the "United Nations Convention Against Transnational Organized Crime" and its two Additional Protocols, Article 7 "Measures to combat money laundering"

1.Each State Party need to:(a) establish a comprehensive domestic regime, the regulatory and supervisory framework for banks and non-banking financial institutions within its competence, in order to deter and detect all forms of money laundering regime who shall emphasize requirements for customer identification, document storage and reporting of suspicious transactions;(B) without prejudice to the provisions of Articles 18 and 27 of this Convention, ensure that administrative, regulatory, law enforcement and other authorities who are devoted to the fight against money laundering (including the judicial authorities, as provided for by domestic legislation), have the ability to cooperate and exchange information at the national and international levels within the conditions prescribed by its domestic legislation. To this end, States Parties should consider the creation of an intelligence unit in finance that will serve as a center for collecting, analyzing and disseminating information relating to possible money cleaning

2.States Parties shall take into account the implementation of appropriate measures to detect and monitor the movement of cash and appropriate negotiable instruments across their borders, subject to safeguards to ensure proper use of information and without impeding in any way movement of legal capital. These measures may include a requirement that individuals and businesses report the activities of cross-border transfers of large amounts of cash and appropriate negotiable instruments

3.States Parties are called upon, during the creation of a regulatory and supervisory regime under the terms of this article, and without prejudice to other articles of this Convention, to be directed to the relevant regional initiatives, interregional and multilateral organizations that fight against laundering money

4.States Parties shall endeavor to develop and promote global, regional, subregional and bilateral cooperation among financial

regulators, judicial and law enforcement in order to combat money-laundering

${ }^{9}$ Dr.Hasan Shkëmbi "Albanian Police, historical and analytical look, Tirana, 2014, page 275 
The Security Council of the United Nations Resolution No.1617, dated 29.07.2005, strongly urged all Member States to fully implement international standards embodied in the Forty Recommendations on money laundering and nine special recommendations of FATF on terrorist financing. ${ }^{1}$

At the origin of money laundering is any criminal activity, also held out, which generates money, often called "dirty", and/or other goods. Therefore, in order to assess, study and reaching conclusions and findings, and providing relevant recommendations, we analyze the statistics, data and trends reports conducted at the Financial Intelligence Unit of Albania, ${ }^{2}$ called since the creation in 2001 as Coordination Directorate of the Fight Against Money Laundering (DBLKPP) with legal status determined by the Council of Ministers ${ }^{3}$ and since 2005 and with the law of $2008^{4}$ raised in the level of the General Directorate for Prevention of Money Laundering ${ }^{5}$ (DPMN).

\section{The most common typologies of money laundering in Albania}

Table No.1 present aggregated data from the annual reports of the department of prevention of money laundering for 20082015.6

\begin{tabular}{|l|l|l|l|l|l|l|l|l|l|}
\hline \multirow{2}{*}{ Sender } & \multicolumn{6}{|l|}{ THE NUMBER OF RAD BY YEARS } \\
\cline { 2 - 11 } & 2008 & 2009 & 2010 & 2011 & 2012 & 2013 & 2014 & 2015 \\
\hline $\begin{array}{l}\text { BANKS \& FINANCIAL } \\
\text { INSTITUTIONS }\end{array}$ & 142 & 173 & 166 & 337 & 425 & 473 & 912 & 681 \\
\hline BANKs & 142 & 173 & 163 & 329 & 352 & 420 & 822 & 585 \\
\hline Transfers Associations & - & - & 3 & 7 & 73 & 45 & 74 & 79 \\
\hline $\begin{array}{l}\text { Foreign exchange bureaus - } \\
\text { Foreign currency exchange office }\end{array}$ & - & - & - & 1 & & 8 & 16 & 17 \\
\hline NON-FINANCIAL OCCUPATIONS & - & 1 & 6 & 18 & 19 & 16 & 126 & 304 \\
\hline Notary & - & 1 & 6 & 17 & 19 & 15 & 122 & 303 \\
\hline Accountants Experts & - & - & - & 1 & - & 1 & 4 & 1 \\
\hline PUBLIC INSTITUTIONS & 7 & 12 & 22 & 28 & & 66 & 162 & 262 \\
\hline CD- Customs Department & 5 & - & 15 & 20 & 30 & 36 & 48 & 45 \\
\hline DT - Department of Taxation & 2 & 1 & 1 & - & 33 & 10 & 50 & 7 \\
\hline CIPRO - Mortgages & - & - & - & 8 & 29 & 20 & 64 & 210 \\
\hline $\begin{array}{l}\text { HIDA - Inspectorate for the } \\
\text { Declaration of Assets }\end{array}$ & - & 10 & 6 & - & 2 & - & 6 & - \\
\hline OTHER & 3 & 1 & 12 & - & 4 & 1 & 3 & 5 \\
\hline TOTAL & 152 & 186 & 211 & 383 & 556 & 558 & 1230 & 1319 \\
\hline
\end{tabular}

Note:Data are obtained from official WEB of the Department of Prevention of Money Laundering (Processing copyright 2016)

As seen from the reporting table of suspicious activity (RAD) the majority is occupied by the reports from the banking system. So in $2008,{ }^{7}$ reported by banks they occupy $94 \%$ of all the reported RADs near the Albanian Financial Intelligence

\footnotetext{
${ }^{1}$ Anti-Money Laundering:International Law and Practice.Edited by W.H.Muller, C.H.K”alin and J.G.Goldsworth-2007, John Wiley ^ Sons, Ltd, faqe 71 (Taken from Dr. Naim Mëçalla" Money laundering -Elements of criminal justice and criminology ", Tirana 2013, page 19-20) 2http://www1.fint.gov.al/al/historiku/njesia-e-inteligjences-financiare-shqiptare

3Law No.9084, dated 19.06.2003 "On some amendments to Law No. 8610, dated 17.05.2000 "On Prevention of Money Laundering" ${ }^{4}$ Law No. 9917, dated 19.15.2008, "On the prevention of money laundering and terrorist financing"

5Decision No.108, dated 11.2.2005 of the Council of Ministers "On the organization, operation and salaries of employees of the General Directorate for Prevention of Money Laundering", Official Gazette No.10, dated 16.03.2005, 1. The organization of the General Directorate for Prevention of Money Laundering (DPMN), as the central budget institution,, according to the Minister of Finance. The General Directorate for Prevention of Money Laundering its activities with the aim of preventing and combating crime in the area of money laundering, terrorist financing and financial crime in general

${ }^{6}$ Annual report of the General Directorate of Prevention and Money Laundering, 2008, 2009, 2010, 2011, 2012, 2013, 2014,2015

http://www1.fint.gov.al/images/Raportet_vjetore/Raporti\%20vjetor\%20shqip\%202008.pdf
}

${ }^{7}$ Annual report of the General Directorate of Prevention and Money Laundering, 2008 
Unit ${ }^{1}$ or 142. This volume declines and in the past two years when the growth of RAD in item appears bigger in 1230 and 1319, the specific weight that banks occupy in their reporting falls to $67 \%$ in 2014 and $45 \%$ in 2015.

In the second place that have the trend of higher growth during the period under study, there are the free professions, and within this group, notary profession is much more collaborative out and in reports. So if in 2008 and 2009 we have RAD 0 and 1 respectively, in 2014 and in 2015 they go on 122 and 303 RAD.

If those trends will be studied by 0 for 2008 amounting to $23 \%$ of the volume of RAD reported by notaries, which it is a significant figure compared with the region and all other countries. Registration Offices of Real Estate or as known in the jargon of the day-mortgages have begun to report RAD for the first time in 2011, ${ }^{2}$ having a progressive growth trend with 2010 in 2015. ${ }^{3}$ In specific weight in 2009 whether this public institution didn't report at all in $2011,{ }^{4}$ it occupies $2 \%$ of RAD and in 2015 it reaches the amounts to $16 \%$ of the total number of RAD . ${ }^{5}$

Detection of RAD by some public institutions such as customs administration and fiscal,have unusual trends or even ZRPPP gives the impression that RADs are strained, they do not grow naturally, but also depend on other subjective factors (steering, commitment, political forces that guide, etc.). If we observe the Directorate General of Taxation we see that they have their peak in 2012 by $33 \mathrm{RAD}$ and in $2014^{6}$ with $50^{7}$ having in the years ahead minimum single digit figures Also, customs have a peak in $2014^{8}$ with a trend getting lower.

\section{The most prevalent forms through the banking system of money laundering in Albania, with specific data}

Analyzing the 2011 Annual Report of the Department of Prevention of Money Laundering ${ }^{9}$ (DPMN) given an interesting clue that $36 \%$ of the RAD report occupy those associated with bank transfers to abroad. Certainly in an unformalized economy, not all such transfers are necessarily related to the offense of money laundering, but taking into account their amounts and typologies, banks have reported as suspicious because the source of the creation of these funds is not declared from the legal income-generating activities.

In second place with $16 \%$ of the total number of suspicious activity reports (SAR) is the typology of the use of individual accounts for business purposes, or as otherwise known as tax evasion.To escape the payment of taxes, more partners or business leaders commit a good portion of their transactions through individual accounts and not of the companies, making it difficult to further the work of the tax and law enforcement in the allocation of these transactions into "black" or "gray". In third place with $13 \%$ of the RAD, cash deposits in banks in significant amounts and still without a known source or without considering the second-tier banks. For more information about these databases also we are presenting this chart compiled by the Albanian financial intelligence unit in this report VII of the Department of Prevention and Money Laundering. ${ }^{10}$

The analysis of the available data, we see that the suspicious transfers, deposits in cash in substantial amounts and the use of individual accounts for business purposes, or as it is known commonly "evasion" are three typologies which together made up $65 \%$ of the reports for the year $2011,60 \%$ of RAD in 2012 and $59 \%$ of them in 2013. Their tendency to discount is explained by the fact that the training conducted by national and international organizations as well as DPMNP, have made it possible that the reporting entities increase the typologies and the range of reasonable suspicion of money laundering.

These typologies began to be analyzeed in 2010 , first as a qualitative step in the analysis that performed FIU11 as the unit of financial intelligence and continues in the years 2011, 2012 and 2013. ${ }^{12}$

\footnotetext{
${ }^{1}$ The source is obtained by analyzing data provided by DPMN on its official portal: www1.fint.gov.al

${ }^{2}$ Annual report of the General Directorate of Prevention and Money Laundering, 2011

${ }^{3}$ Annual report of the General Directorate of Prevention and Money Laundering, 2015

${ }^{4}$ Annual report of the General Directorate of Prevention and Money Laundering, 2011

${ }^{5}$ Annual report of the General Directorate of Prevention and Money Laundering 2015

${ }^{6}$ Annual report of the General Directorate of Prevention and Money Laundering, 2012

${ }^{7}$ Annual report of the General Directorate for Prevention of Money Laundering, 2014

$8 \mathrm{lbid}$

${ }^{9}$ Annual report of the General Directorate of Prevention and Money Laundering, 2011

${ }^{10}$ www1.fint.gov.al

${ }^{11}$ Annual report of the General Directorate of Prevention and Money Laundering 2010

${ }^{12}$ Annual report of the General Directorate of Prevention and Money Laundering, 2011, 2012, 2013 presented in its official

portal:www1.fint.gov.al
} 
Table No.2 present typologies of RAD by $2010-2013 .{ }^{1}$

\begin{tabular}{|c|c|c|c|c|}
\hline Typology of RAD in years & 2010 & 2011 & 2012 & 2013 \\
\hline Suspicious transfers & 63 & 141 & 218 & 189 \\
\hline Pouring cash in substantial amounts & 30 & 53 & 60 & 96 \\
\hline $\begin{array}{l}\text { The use of individual account for business / tax } \\
\text { evasion }\end{array}$ & 53 & 62 & 52 & 44 \\
\hline Operations outside the profile of the customer & 11 & 18 & 29 & 60 \\
\hline Suspicions related to import / export of goods & 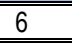 & 16 & 19 & 13 \\
\hline Statement / statement of values not at the border & 4 & 5 & 11 & 23 \\
\hline Fraud and computer fraud & 11 & 9 & 1 & 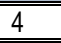 \\
\hline PEP involvement in transactions & 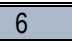 & 7 & 9 & 0 \\
\hline Suspicion of terrorism financing & 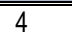 & 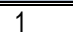 & 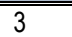 & 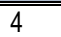 \\
\hline $\begin{array}{l}\text { Sponsorships / donations / loan award from / to } \\
\text { third }\end{array}$ & 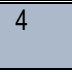 & 0 & 15 & 18 \\
\hline $\begin{array}{l}\text { Purchase of real estate with unknown source of } \\
\text { funds }\end{array}$ & 0 & 15 & 37 & 29 \\
\hline $\begin{array}{l}\text { Purchase of real movable with unknown source } \\
\text { of funds }\end{array}$ & 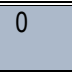 & 0 & $\overline{77}$ & 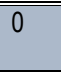 \\
\hline Not identifying the beneficial owner & 0 & 11 & 24 & 1 \\
\hline Attempted remaining actions & 0 & 8 & 17 & 26 \\
\hline Transactions carried out by NGOs & 0 & 2 & 5 & 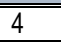 \\
\hline Making a fictitious economic activity & 0 & 20 & 23 & $\overline{5}$ \\
\hline $\begin{array}{l}\text { Transactions carried out from / to gambling } \\
\text { companies }\end{array}$ & 0 & 5 & 7 & 2 \\
\hline $\begin{array}{l}\text { Actions by persons suspected of involvement in } \\
\text { criminal activity }\end{array}$ & 0 & 8 & 0 & 9 \\
\hline $\begin{array}{l}\text { Use banking instruments anomalies / counterfeit } \\
\text { (letter of credit / check, etc.) }\end{array}$ & 0 & 0 & 5 & 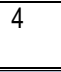 \\
\hline Suspicious use of bank loans & 0 & 4 & 3 & 8 \\
\hline Other (unspecified) & 19 & 10 & 11 & 19 \\
\hline AMOUNT & 211 & 383 & 556 & 558 \\
\hline
\end{tabular}

Source: Annual Report of the Directorate General of Prevention and Money Laundering, 2010, 2011, 2012, 2013. Processing Copyright (2016)

As for the years 2014 and 2015, the main typologies of RAD, they don't have a precise and exact division, as before, to see their trends and their movements, but they are provided only listed more or less as before, as follows: ${ }^{2}$

Suspicious transfers to / from the outside;

Pouring cash in substantial amounts

The use of individual account for business purposes

Tax evasion

Operations outside the customer profile

Suspicions related to import / export of goods

Suspicion of terrorism financing

Not identifying the beneficial owner

Transactions carried out from / to gambling companies

Suspicious use of bank loans

\author{
Statement / statement of values not at the border \\ PEP involvement in transactions \\ Purchase of real estate / movable with unknown source of funds \\ Sponsorships / donations / loan award from / to third \\ fraud; \\ Actions / transactions remaining attempt \\ Transactions carried out by NGOs \\ Making a fictitious economic activity \\ Use of bank anomalies (letter of credit / check, etc. \\ Currency swaps to high values.
}

\footnotetext{
${ }^{1}$ Annual report of the General Directorate of Prevention and Money Laundering, 2010,2011,2012,2013

${ }^{2}$ Annual report of the General Directorate of Prevention and Money Laundering, 2014, 2015
} 


\section{The most common forms through the real estate sector of money laundering in Albania, with specific data}

The construction sector and real estate market have been a free zone for injecting money laundering in Albania as well as in the region. Mass privatization, not establishing clear rules since the beginning, not returning since the beginning the property to the owner, corruption in mortgages, granted a building permit and in the courts as well as problems with property titles, issues still not resolved definitively in Albania It has produced many serious social conflicts, to taking a life. In these conditions, money laundering has flourished through the purchase of land, houses, hotels, restaurants or their construction. Usually people, mostly relatives (father, brother, brother in law, sister, etc.) that invest in real estate on behalf of individuals who have previously committed offenses abroad and the money that they have earned they bring them to the relatives, friends to invest in real estate.

From the open sources, DPMN gives typology of these cases in its annually reports, what indicates that these cases are encountered frequently, and in terms of statistical data, data are only for a few reports of suspicious activity-RAD, that are associated with the purchase of real estate with unknown source of funds, which in years appear so:

\begin{tabular}{|l|l|l|}
\hline Nr. & Years & RAD \\
\hline 1 & 2011 & 15 \\
\hline 2 & 2012 & 37 \\
\hline 3 & 2013 & 29 \\
\hline
\end{tabular}

Regarding recent years, as we said above, these data do not appear to specify figures, but it is the same typology it is expressed in words, but without specifying the quantitative measurement. I think it is the duty of state institutions, not only of DPMN, but also of ZRPPP, of the Police, of the Prosecution and of the Courts to identify, register and submit more real estate generated from criminal sources, which are taking measures of preventive seizures and conservative or confiscate them and when there are fully proven the origin offenses and money laundering through this form, which unfortunately has found ground in Albania.

Annual Report 2015, published recently by FIU, ${ }^{1}$ presents problems in this area. Thus, the report says: RAD directly related to the disposal of real estate (RAD by notaries and ZQRPP) have marked a significant increase compared to every other year and they occupy $41 \%$ of total RAD for 2015 , but there results still problems in terms of description and reasoning of these RADs to be addressed in the subjects and their supervisory authorities.

\section{The most common forms through transfer companies and foreign exchange bureaus of money laundering in Albania, with specific data}

By reading typologies presented in the Annual Report $2012,{ }^{2}$ it shows a typology related to transfers from countries from which there is usually no sending remittances or no trading exchanges.And in the case of the transfers in substantial sums they are committed by some countries of Africa and from two Oceanic countries, that are unrelated to Albania, because there is no Albanian emigration and the trade exchanges are minimal. Likewise, typologies are looked increasingly that they are used always third parties to conceal the transfer, the ownership and the real source of money.

Table No.3 present table with reporting entities /RAD according to the years 2010 to $2015 .^{3}$

\begin{tabular}{|l|l|l|l|l|l|l|}
\hline REPORTING ENTITY/ RAD ACCORDING TO YEARS & 2010 & 2011 & 2012 & 2013 & 2014 & 2015 \\
\hline 1 & 2 & 3 & 4 & 5 & 6 & 7 \\
\hline Transfers society & 3 & 7 & 73 & 45 & 74 & 79 \\
\hline
\end{tabular}

Source :Annual Report of the Directorate General of Prevention and Money Laundering, 2010,2011,2012,2013, 2014, 2015.

Processing Copyright (2016)

\footnotetext{
${ }^{1}$ Annual report of the General Directorate of Prevention and Money Laundering, 2015 www1.fint.gov.al

2 lbid

${ }^{3}$ www1.fint.gov.al
} 
We see that companies are starting to report transfers RAD for the first time in $2010,{ }^{1}$ with 3 cases. In the coming years it seems to have an awareness of this sector that increases the number of RAD, eventhough we have no data for their quality, or for the typologies where there are determined as:

$\square$ transfers sent from abroad by various citizens towards a recipient and vice versa;

प structured transfers from countries considered at risk such as tax havens;

$\square$ transfers from countries where there is no sending remittances or trading exchanges;

One element that I think is important to highlight is the fact that emerges from sectoral analysis conducted in $2015^{2}$ for companies of transfers, where it appears that their RAD have been an important resource, which served as indications for referral in law enforcement for 30 cases, or nearly $13 \%$ of the total of all references.

\section{The most common forms of money laundering by free non-financial professions and other forms in Albania, with specific data}

Money laundering as a phenomenon associated with criminal organizations and helps them hide from law and punishment has been sophisticated. In this regard, if in the past the money could be brought $\mathrm{CASH}$, because there was no control on the border, the deposited CASH, because until 2008 were not required at all the origin of money or reporting of cash transactions above a certain threshold and direct investment in the purchase of real estate management or luxury items, this process has become more difficult and criminals are seeking the assistance of the liberal professions (notary, lawyer, auditor, accountant, evaluation, etc.) to assist in the laundering of dirty money. Likewise, the typologies presented by DPMN, ${ }^{3}$ is seen that are starting to become visible investment by companies established in the countries "paradise" fiscal or establishment of Albanian companies with shareholders society of these "paradise" tax, which hide the real beneficiarie owner. Similarly, criminals, criminal organizations and their assistants of money laundering require that through giving of bribes, favoritism and corruption of elected officials or persons performing functions or public office to make it easier penetration of cash runway into economy.In transition countries like Albania, the regions in general and in the Eastern European countries, corruption has reached levels unimaginable becoming the "cancer" of society, which seriously threatens democratic societies.

Regarding corruption and favoritism from performing category with a risk of high officials or elected to public office, considered PEPs (politically exposed persons), referring to the data of annual reports DPMN, ${ }^{4}$ the number of referrals for these cases is low and can be counted by the fingers of the hand.

5 years in total in this category are referred to 39 cases or $2.5 \%$ of the total number of referrals, human trafficking, corruption, etc not declared at the border etc .In this aspect as the Unit of Financial Intelligence unit as well as law enforcement authorities have a lot of work to do, because the pursuit of money is the most efficient way to combat this canker of the XXI century, as is corruption. In this context as one of the most important planetary developments we can specify the high-level meeting on "Anti Corruption" held on 12 May 2016 in London, under the auspices of the Prime Minister of the United Kingdom Mr. David Cameron, as the first of its kind, bringing together leaders from many countries, civil society and business organizations, who agreed to a series of concrete measures such as:

Disclosure of corruption - that can not be disguised from the law and from dealing with people

1.1 By exposing lawyers, notaries, agents of real estate sales accelerate it or who are part of the corruption issues, by passing legal routes of business development,

\footnotetext{
${ }_{1}^{1}$ Annual report of the General Directorate of Prevention and Money Laundering 2010

${ }^{2}$ Annual report of the General Directorate of Prevention and Money Laundering, 2015

${ }^{3}$ www1.fint.gov.al

${ }^{4}$ lbid
} 
1.2 By increasing the transparency of budgetary expenditures by governments, tax and procurement information to expose tax concealment and abuse of taxpayer dollars,

\subsection{By creating opportunities to citizens to report cases of corruption without fear of retribution.}

\section{Punishment of persons who commit corruption and assistance to those who are injured by corruption}

\subsection{By strengthening the anti-corruption laws and working together to prosecute the corrupt and their legal punishment}

2.2 Detecting and returning the stolen assets to their legitimate owners, ie to the people stolen by corrupt;

2.3 By making it clear to corrupt that there is no exemption from punishment for those anywhere in the world.

\section{The establishment of a working anti corruption culture at all levels and in all countries}

\subsection{By uncompromising fight corruption}

3.2 By providing clarity in governance in key areas of the economy, but also including sports, playing games, etc.

3.3 By using new inventions and technologies to enable citizens to help in the fight against corruption.

3.4 By encouraging international organizations to enhance the fight against corruption and coordination of their work more effectively.

As we have noted above, DPMN is the unit on Financial Intelligence, but the Administrative type (without power probe), which on the basis of confidential information of state bodies or open-source, managed to determine a potential link with work origin of some of the cases referred to, which have been categorized and summarized as follows for the period 20112015 , and the total for the past 5 years.

Table No.4 present money laundering offenses based on the origin, 2011-2015.

\begin{tabular}{|l|l|l|l|l|l|l||}
\hline References to money laundering offenses based on origin & 2011 & 2012 & 2013 & 2014 & 2015 & TOTALI \\
\hline 1 & 2 & 3 & 4 & 5 & 6 & $7=2+3+4+5+6$ \\
\hline \hline Narcotics trafficking & 25 & 30 & 18 & 50 & 48 & 171 \\
\hline Fraud / Forgery & 6 & 16 & 17 & 20 & 20 & 79 \\
\hline Concealment of income / Tax evasion & 11 & 15 & 28 & 40 & 38 & 132 \\
\hline Corruption / PEP & 5 & 9 & 7 & 7 & 11 & 39 \\
\hline Robbery / Theft & 4 & 5 & 2 & 10 & 5 & 26 \\
\hline Trafficking in motor vehicles & 2 & 5 & 2 & 2 & -11 \\
\hline Human trafficking / prostitution & 4 & 4 & 4 & 9 & 6 & 27 \\
\hline Other criminal record & & - & 3 & 15 & 16 & 34 \\
\hline Murder / kidnapping & 1 & - & - & 2 & 3 & 6 \\
\hline Do not declare the border & & 1 & - & 4 & 14 & 19 \\
\hline Smuggling and manufacturing / sale of dangerous substances & 1 & 2 & 1 & - & 2 & 6 \\
\hline Criminal proceedings for money laundering & & - & 2 & - & 4 & 6 \\
\hline Suspicion of terrorism financing & 1 & 1 & 1 & 3 & 2 & 8 \\
\hline Creation of criminal organization & & - & 1 & - & 6 & 7 \\
\hline Unlicensed Kambizëm & & - & 1 & - & - & 1 \\
\hline Active exercise of unlicensed gambling & - & - & - & 3 & 3 \\
\hline $\begin{array}{l}\text { It's hard to define the origin of the criminal money that has } \\
\text { generated }\end{array}$ & 151 & 117 & & 300 & 224 & 988 \\
\hline Total & 211 & 205 & 283 & 462 & 402 & 1563 \\
\hline \hline
\end{tabular}

${ }^{1}$ Annual report of the General Directorate of Prevention and Money Laundering, 2011,2012,2013,2014,2015 
Source: Annual Report of the Directorate General of Prevention and Money Laundering, 2011, 2012, 2013, 2014, 2015.Processing Copyright (2016)

As seen from the table, they dominate the cases for which the parent offense (of origin) has not been possible to determine, which account for the entire period of 5 years about $2 / 3$ of the total number of referrals to the police and prosecutor.In most of these cases DPMN has concluded that the circulated funds have not legal source or the ecoomic-loyal purpose have been suspicious. These are very few cases that are investigated further by the law enforcement bodies and remain only as statistical data for the Financial Intelligence Unit without an impact in the fight against money laundering. Of the cases for which it was possible to individualize and determined the origin act, dominate the trafficking of narcotics with 171 cases or $11 \%$ of the cases referred, followed by concealment of income /tax evasion by 132 (or $9 \%$ ) cases signposted and in third place are the offenses of fraud and forgery with 79 cases, or $5 \%$ of the total.I think that this categorization according to origin should continue to be given special attention in the future by DPMN to increase as more people discoverability of money laundering, its effectiveness and identify trends and typologies for rating clear risk to the country.

DPMN is in this context one of the first institutions that has begun risk assessment in 2012 by sending it to all relevant institutions in the country, supervisory bodies, financial institutions and further conclusions were shared with law enforcement authorities. In order to summarize the conclusions of a risk assessment reviewed in 2015 and were to be attacked or taken into consideration by all actors and factors are:

On the basis of the alignment with international standards and continuous assistance mainly to the EU, it has been worked to establish a system of effective deterrent and currently the system works, although there are sectors that need to be reassessed in depth to ensure continuity of reporting and their diversity, but the level of supervision proffessions, gambling, traders of precious metals and stones, there is room for further improvement.

Given the data, it turns out that the probability of detection of suspicious cases in intelligence is at a good level, but the investigation presents significant problems and this also affects the delivery of very few cases in court.Investigating cases of money laundering autonomously (ie, when the person has committed the offense originating) still remains at low levels.

The efficiency of investigations affects the fact that, for a significant portion of the cases required enforcement of letters rogatory from foreign judicial authorities, execution that is performed too late and that adversely affects in any investigation, leading to decisions dismissal or suspension of criminal proceedings.

Implementation of the Law No. 10 192, dated 3.12.2009 "On preventing and combating organized crime and trafficking through preventive measures against property" of change is very far from the expectations and opportunities that this law grants within the confiscation of criminal products.

Informality in the economy and the use in large-scale of cash remain a problem within the detection and investigation of PP/FT, as it hinder it, and there remains the problem of transport of cash in entry/exit from the points of crossing border after a series of indica concluded that it occurs significantly, but the statements as well as penalties for non-disclosure are minimal.

Risk /main threat identified is the criminal product, who is estimated that it stems mainly from trafficking in narcotics, crimes in tax and customs (such as smuggling, concealment of income, TV fraud) and corruption, the work of these, is thought to dominate the criminal proceeds.

\section{Bibliography}

[1] Prof.Dr. Luan Gjonça, "Corruption, Criminal Component, Organized Crime", ILAR, Tirana, 2005

[2] Dr.Naim Mëçalla "Money Laundering -Elements of criminal justice and criminology", Tirana, 2013

[3] Prof.Dr. Luan Gjonça "Cleaning the proceeds of crime and organized crime", Tirana, 2000

[4] Law No.8610, dated 17.05.2000 "On Prevention of Money Laundering"

[5] Law No.9086, dated 19.06.2003 "On some additions and amendments to Law No.7895, dated 27.01.1995 "The Criminal Code of the Republic of Albania" 
[6] Convention of the Organization of the United Nations against International Organized Crime, Palermo 2000

[7] Law No.8920, dated 11.7.2002 On the ratification of the "United Nations Convention Against Transnational Organized Crime" and its two Additional Protocols

[8] Dr.Hasan Shkëmbi "Albanian Police, historical and analytical look", Tirana 2014

[9] Anti-Money Laundering:International Law and Practice.Edited by W.H.Muller, C.H.K "alin and J.G.Goldsworth-2007, John Wiley ^ Sons, Ltd

[10] Law No.9084, dated 19.06.2003"On some amendments to Law No.8610, dated 17.05.2000 "On Prevention of Money Laundering"

[11] Law No.9917, dated 19.15.2008,"On the prevention of money laundering and terrorist financing"

[12] Decision No.108, dated 11.2.2005 of the Council of Ministers "On the organization, operation and salaries of employees of the General Directorate for Prevention of Money Laundering"

[13] Annual report of the General Directorate of Prevention and Money Laundering,2008

[14] Annual report of the General Directorate of Prevention and Money Laundering,2009

[15] Annual report of the General Directorate of Prevention and Money Laundering,2010

[16] Annual report of the General Directorate of Prevention and Money Laundering,2011

[17] Annual report of the General Directorate of Prevention and Money Laundering,2012

[18] Annual report of the General Directorate of Prevention and Money Laundering,2013

[19] Annual report of the General Directorate for Prevention of Money Laundering,2014

[20] Annual report of the General Directorate of Prevention and Money Laundering,2015

[21] http://www1.fint.gov.al/al/historiku/njesia-e-inteligjences-financiare-shqiptare

[22] http://www1.fint.gov.al/images/Raportet_vjetore/Raporti\%20vjetor\%20shqip\%202008.pdf

[23] http://juridiksi.e-monsite.com/faqe/e-drejta-penale/pastrimi-i-parava-te-pista.html

[24] www1.fint.gov.al 